\title{
PENGARUH LAMA PEMERAMAN DAN JENIS KERTAS PEMBUNGKUS TERHADAP KUALITAS SIFAT ORGANOLEPTIK DAN KIMIA BUAH PISANG AMBON (Musa paradisiaca var. sapientum $L$ )
}

\author{
Sevia Dwi Suryanti ${ }^{(1)}$, Mulono Apriyanto ${ }^{(2)}$, dan Lana Santika Nadia ${ }^{(3)}$ \\ (1) Mahasiswa Universitas Alma Ata Yogyakarta \\ (2) Dosen Teknologi Pangan UNISI, Riau \\ mulonoapriyanto71@gmail.com \\ (3) Dosen Universitas Alma Ata Yogyakarta
}

\begin{abstract}
Abstrak
Penelitian ini bertujuan untuk mengetahui pengaruh waktu dan jenis kertas pembungkus pada pemeraman buah pisang ambon (Musa paradisiaca var. sapientum $L)$ terhadap kualitas sifat organoleptik dan kimia. Jenis penelitian yang dilakukan adalah eksperimental dengan menggunakan rancangan penelitian yaitu RAK (Rancangan Acak Kelompok). Jenis pisang yang digunakan dalam penelitian ini adalah pisang ambon kuning dengan 1 kontrol dan 2 perlakuan, berupa pisang ambon yang diperam menggunakan kertas kraft polos dan kertas kraft bertinta sebesar $20 \%$ dari berat pisang.

Hasil penelitian menunjukkan bahwa lama pemeraman terdapat pengaruh yang nyata $(\mathrm{p}<0,05)$ terhadap sifat kimia yaitu vitamin $\mathrm{C}$ dan gula reduksi. Kadar Vitamin $\mathrm{C}$ dan gula reduksi meningkat selama proses pemeraman, nilai tertinggi terdapat pada hari ke-5 pemeraaman yaitu $84,48 \mathrm{mg}$ untuk vitamin $\mathrm{C}$ dan 5,90\% untuk gula reduksi. Pada jenis kertas pembungkus terdapat pengaruh yang nyata $(p<0,05)$ terhadap sifat kimia yaitu vitamin $\mathrm{C}$ dan gula reduksi. Jenis kertas pembungkus bertinta dapat mempercepat proses pematangan. Uji organoleptik (rasa, aroma, warna, tekstur) yang paling banyak disukai panelis adalah buah pisang ambon kuning dengan media pemeraman kertas bertinta.
\end{abstract}

Kata Kunci : pisang ambon, waktu pemeraman, jenis kertas pembungkus

\section{PENDAHULUAN}

Produksi pisang di Indonesia menduduki urutan keenam setelah India, Ekuador, Brazil, Filippina, dan Cina. Dari produksi pisang yang dihasilkan di Indonesia, 90\% untuk konsumsi dalam negeri, sedangkan untuk ekspor hanya $10 \%$ (Suhartanto, 2012).

Pisang merupakan salah satu tumbuhan yang paling banyak tumbuh di daerah tropis seperti Indonesia. Pisang merupakan buah yang tumbuh berupa kultivular, memiliki kandungan gizi tinggi, seperti vitamin $\mathrm{C}$, vitamin $\mathrm{A}$, kalsium, mineral, dan karbohidrat. Kandungan gizi yang terdapat dalam pisang ambon adalah $99 \mathrm{kkal}, 25,80 \%$ karbohidrat, 146 SI vitamin A, $3 \mathrm{mg}$ vitamin C, dan 75\% air (Gardjito, 2013). Pisang termasuk buah yang sangat 
mudah untuk didapat, karena pisang terus berbuah tanpa mengenal musim dan pertumbuhannya relatif cepat.

Pisang merupakan buah yang tergolong dalam buah klimaterik. Klimaterik merupakan suatu fase yang kritis dalam kehidupan buah, dan selama terjadinya proses ini banyak sekali perubahan yang berlangsung. Proses ini dapat diartikan sebagai suatu keadaan auto stimulation dari dalam buah sehingga buah menjadi matang yang disertai dengan adanya peningkatan proses respirasi (Muchtadi, 2011).

Dewasa ini masyarakat, pedagang pisang, dan para petani pisang banyak yang menggunakan karbit untuk memeram pisang agar mempercepat proses pematangan. Menurut Prabawati dkk (2008) kelemahan menggunakan batu karbit buah cepat rusak ditandai dengan bintik-bintik coklat pada permukaan kulit. Kerusakan pada buah ini akibat dari pemeraman buah yang dilakukan dengan penambahan karbit yang dapat mempercepat laju gas etilen. Kerusakan tersebut sangat tidak sesuai dengan minat pasar yang tinggi terhadap buah pisang (Prabawati, 2008). Selain itu, penggunaan kalsium karbida (karbid) saat ini sudah berkurang terutama di negara-negara maju karena dapat membahayakan bagi kesehatan disebabkan racun arsenik dan phosphorus yang terkandung didalamnya (Asif, 2012).

Ada beberapa cara pemeraman yang sudah digunakan oleh masyarakat sejak zaman dahulu untuk memeram buah pisang selain menggunakan karbit yaitu dengan dimasukan kedalam tempayan, menggunakan daun dan dengan pengasapan. Pemeraman buah pisang menggunakan tempayan membutuhkan waktu sekitar 2-3 hari, karena didalam tempayan suhu dan proses respirasi hanya berada di dalam tempayan. Sedangkan pemeraman menggunakan daun membutuhkan waktu sekitar 3-4 hari untuk mendapatkan kematangan yang seragam, ada beberapa jenis daun yang dapat merangsang pematang buah yaitu daun lamtoro, daun gamal dan daun mindi serta daun pisang. Penggunaan daun membutuhkan waktu yang lebih lama dari penggunaan tempayan karena suhu dan proses respirasi akan keluar ke udara bebas (Zuhairini, 1997).

Kertas dapat mempercepat proses pematangan buah dengan aman, karena kertas memiliki pori-pori yang kecil, sehingga proses respirasi dan etilen terperangkap didalam kertas. Selain itu, kertas sangat mudah didapat di masyarakat.

Berdasarkan paparan di atas, kertas dapat digunakan sebagai alternatif lain yang aman dan dapat digunakan sebagai media untuk memeram buah. Oleh karena itu, perlu dilakukan penelitian untuk mengetahui pengaruh kertas pada pemeraman buah pisang ambon (Musa paradisiaca var. sapientum $L$ ).

\section{METODOLOGI PENELITIAN}

Penelitian dilakukan di Laboratorium Biomedik dan Kuliner Universitas Alma Ata. Pada penelitian ini pisang ambon yang digunakan jenis pisang ambon kuning (Musa paradisiaca var. Sapientum L). Terdapat tiga kelompok pada penelitian ini kelompok 1 (K) merupakan kelompok kontrol (pisang ambon yang di peram di suhu ruang), kelompok $2(\mathrm{P} 1)$ pisang ambon yang diperam menggunakan kertas polos $20 \%$ dari berat buah dan kelompok 3 (P2) pisang ambon yang diperam menggunakan kertas bertinta 20\% dari berat buah. Setiap perlakuan dilakukan ulangan sebanyak 2 kali dengan 2 unit percobaan. Masing-masing perlakuan diamati dan diukur secara harian selama 
5 hari. Pada hari akhir pemeraman atau hari ke 5 dilakukan uji organoleptik deskriptif menggunkan panelis semi terlatih sebanyak 15 orang.

Uji organoleptik deskriptif dilakukan dua kali, yaitu uji organoleptik terbuka dan tertutup. Uji organoleptik terbuka dilakukan untuk persamaan persepsi buah pisang ambon atribut warna, aroma, tekstur, dan rasa yang diinginkan oleh peneliti dengan menggunakan sampel buah pisang ambon yang didapat dari toko buah. Kemudian, dua hari setelah uji organoleptik terbuka, dilakukan uji organoleptik tertutup dengan mengujikan pisang ambon kuning atribut warna, aroma, tekstur, dan rasa yang sudah diperam selama 5 hari menggunakan kertas pembungkus.

\section{Proses Pemeraman Buah Pisang Ambon}

Buah pisang ambon didapat dari petani pisang. Pisang ambon yang dipilih adalah yang disebutkan dalam kriteria inklusi. Pisang ambon yang sudah masuk dalam kriteria inklusi, lalu ditimbang dalam bentuk per buah. Selanjutnya menyiapkan kertas kraft polos dan bertinta, lalu menimbang sebanyak $20 \%$ dari berat buah pisang ambon. Selanjutnya pemasukkan pisang kedalam masing-masing jenis kertas pembungkus. Pisang diperam selama 5 hari dan dianalisis sifat kimianya selama 5 hari (setiap hari), sedangkan sifat organoleptik diujikan pada hari terakhir (hari ke-5) pemeraman.

\section{Penentuan Kadar Vitamin C metode Titrasi Iodimetri}

Analisis kadar vitamin $\mathrm{C}$ diawali dengan menghaluskan pisang dengan blender hingga halus. Setelah halus, sampel ditimbang sebanyak $10 \mathrm{~g}$, ditempatkan pada labu takar dan tambahkan aquadest sebanyak $100 \mathrm{ml}$ dan gojok. Setelah digojok, disaring menggunakan kertas saring, supernatant diambil sebanyak $25 \mathrm{ml}$ dan ditambahkan $2 \mathrm{ml}$ amilum 1\%. Setelah itu, meneteskan larutan iod $0,01 \mathrm{~N}$ sampai berwarna biru. Catat volume titrasi lalu hitung dengan rumus kadar vitamin $\mathrm{C}$.

\section{Penentuan Kadar Gula Reduksi metode Nelson-Somogyi}

Analisis kadar gula reduksi diawali dengan menghaluskan pisang dengan menggunakan blender hingga halus. Menimbang sampel sebanyak $5 \mathrm{~g}$ lalu mengencerkan sampel $250 \mathrm{ml}$ dalam labu takar. Lalu penyaringan menggunakan kertas saring, dan mengambil supernatal $10 \mathrm{ml}$. Lalu diencerkan $100 \mathrm{ml}$ aquades dalam labu takar, menambahkan $1 \mathrm{ml}$ nelson $\mathrm{C}$. Memanaskannya selama 30 menit, kemudian dinginkan. Menambahkan 1 $\mathrm{ml}$ arsenomoligat, lalu menambahkan aquades hingga $10 \mathrm{ml}$. Menggojok menggunakan fortex, kemudian pembacaan gelombang menggunakan spektrofotometer 540 .

Peneliti sangat menyadari bahwa dalam melakukan penelitian serta dalam melaporkan hasil penelitian ini banyak keterbatasan. Keterbatasan-keterbatasan tersebut antara lain :

1. Dalam mencari pisang yang berumur kurang dari 100 hari sehingga harus memesan kepada petani jauh hari sebelum penelitian

2. Dalam melakukan analisis kimia, keterbatasan pendamping dalam mendampingi proses analisis kimia. 


\section{HASIL DAN PEMBAHASAN}

\section{Pengaruh Lama Pemeraman}

\section{a. Vitamin C}

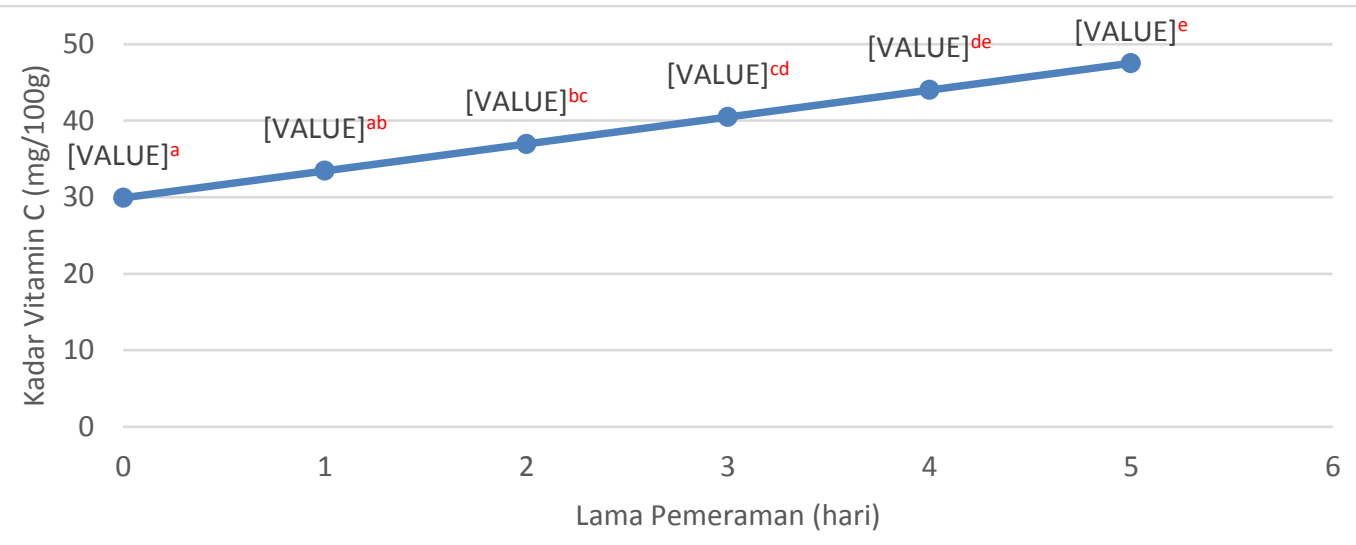

Gambar 1. Kadar Vitamin C pada pisang dengan pemeraman terbuka (kontrol)

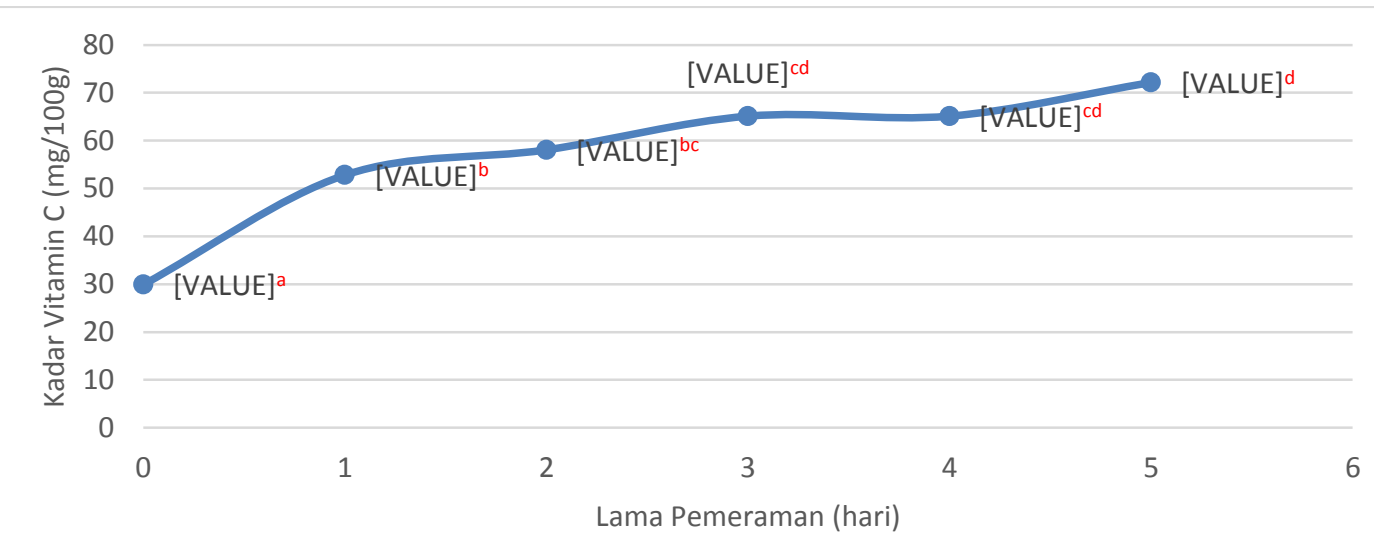

Gambar 2. Kadar Vitamin C pada pisang pemeraman menggunakan kertas polos

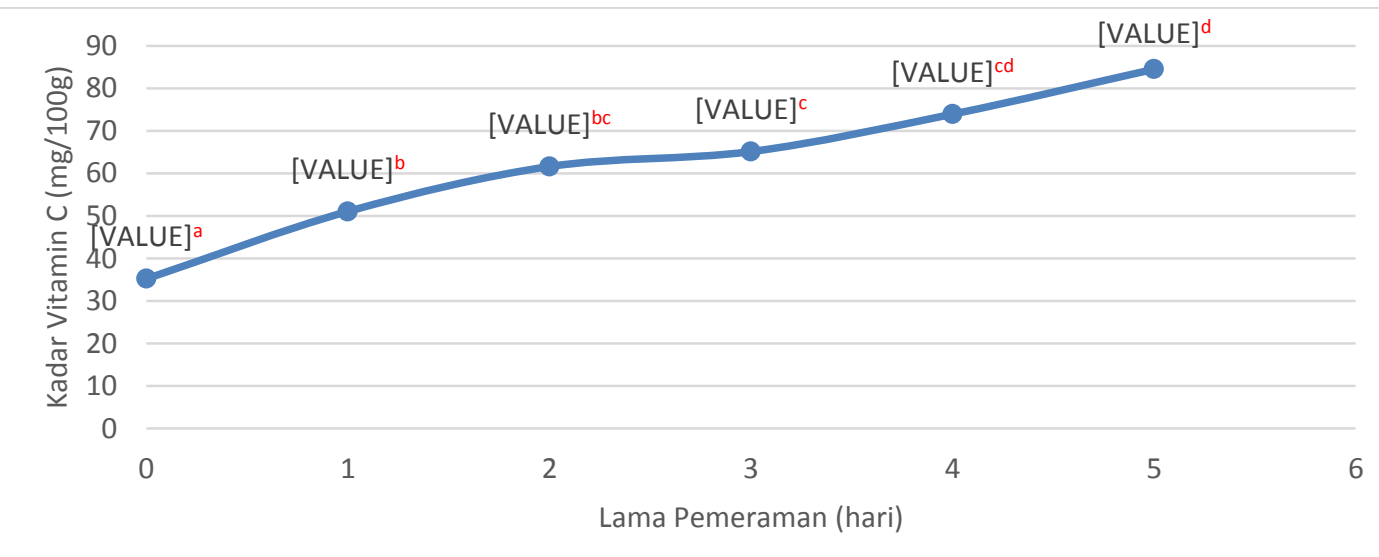

Gambar 3. Kadar Vitamin C pada pisang pemeraman menggunakan kertas bertinta 
Berdasarkan gambar 1, 2, 3 menunjukkan bahwa adanya perbedaan yang nyata $(\mathrm{p}<0,05)$ terhadap lamanya pemeraman dengan meningkatnya kadar vitamin $\mathrm{C}$ yang terdapat pada buah pisang ambon selama pemeraman. Dapat dilihat bahwa kadar vitamin $\mathrm{C}$ yang paling besar terdapat pada hari ke lima, yaitu 84,48 mg. Meningkatnya kadar vitamin $\mathrm{C}$ dapat disebabkan karena sifat buah pisang yang termasuk dalam buah klimaterik. Klimaterik merupakan suatu keadaan auto stimulation dari dalam buah sehingga buah menjadi matang yang disertai dengan adanya peningkatan proses respirasi (Muchtadi, 2011)). Buah klimaterik menghasilkan lebih banyak etilen pada saat matang dan mempercepat serta lebih seragam tingkat kematangannya pada saat pemberian etilen (Sakti, 2008). Buah klimaterik hanya akan mengadakan reaksi respirasi apabila etilen diberikan dalam tingkat pra klimaterik dan tidak peka lagi terhadap etilen setelah kenaikan respirasi dimulai (Pantastico,1993) .

Menurut Harris dan Karmas (1989), yang menyatakan bahwa selama proses pematangan, akan terjadi peningkatan kadar vitamin C. Hal ini disebabkan karena peningkatan asamasam pada pisang termasuk asam askorbat (vitamin C). kadar asam askorbat pisang akan meningkat bila diperam dari keadaan hijau menjadi kuning kecoklatan (Harris, 1989).

\section{b. Gula Reduksi}

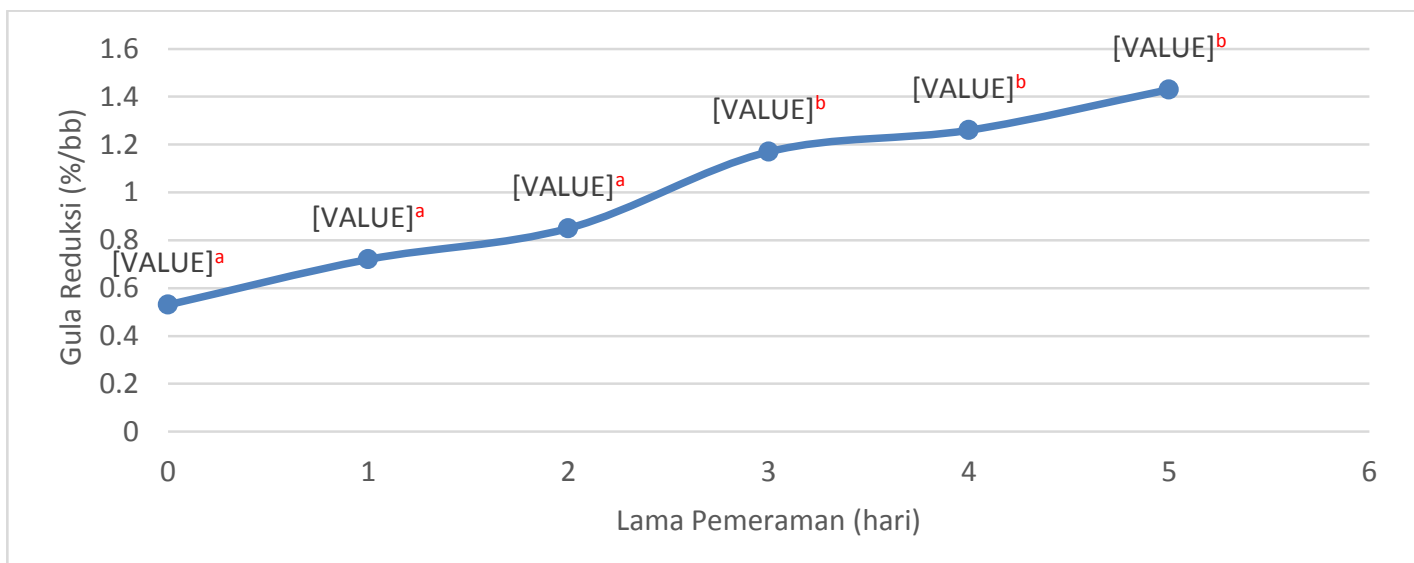

Gambar 4. Kadar Gula Reduksi pada pisang dengan pemeraman terbuka (kontrol) 


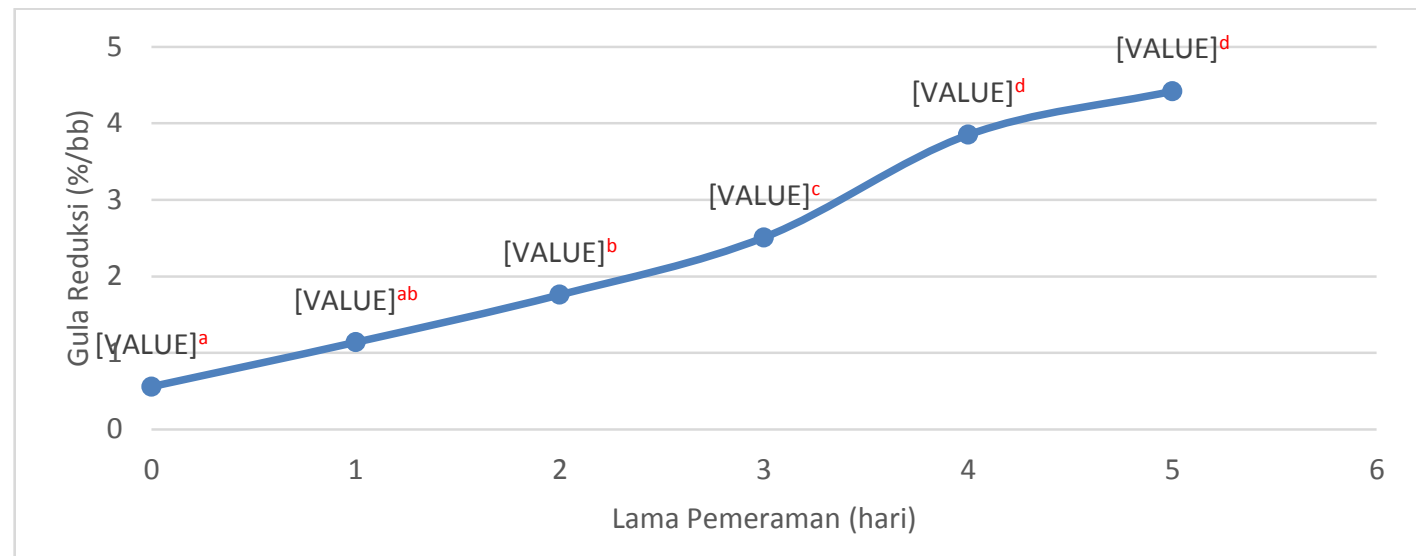

Gambar 5. Kadar Gula Reduksi pada pisang pemeraman menggunakan kertas polos

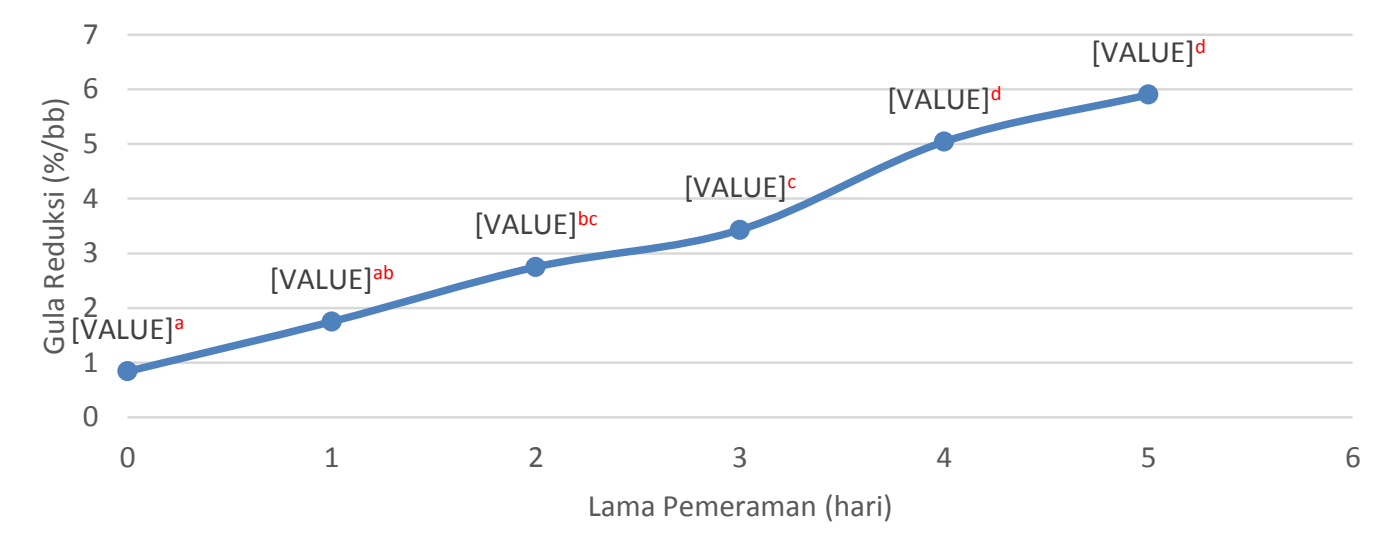

Gambar 6. Kadar gula reduksi pada pisang pemeraman menggunakan kertas bertinta

Berdasarkan gambar 4;5;6 menunjukkan bahwa adanya perbedaan yang nyata $(p<0,05)$ terhadap lamanya pemeraman dengan meningkatnya kadar gula reduksi yang terdapat pada buah pisang ambon selama pemeraman. Kadar gula reduksi tertinggi terdapat pada pemeraman hari ke-5 yaitu 5,90\%. Menurut Mahapatra dkk (2010) selama proses pematangan buah pisang terjadi penurunan kandungan pati dari $20-30 \%$ pada buah pisang yang mentah menjadi $1-2 \%$ pada buah pisang yang matang, sedangkan kandungan gula meningkat dari $1-2 \%$ pada buah pisa mentah menjadi $15-20 \%$ pada buah pisang matang (Muchtadi, 2011).

Meningkatnya kadar gula reduksi dapat disebabkan karena sifat buah pisang yang termasuk dalam buah klimaterik. Klimaterik merupakan suatu keadaan auto stimulation dari dalam buah sehingga buah menjadi matang yang disertai dengan adanya peningkatan proses respirasi (Prabawati, 2008). Buah klimaterik menghasilkan lebih banyak etilen pada saat matang dan mempercepat serta lebih seragam tingkat kematangannya pada saat pemberian etilen (Asif, 2012). Buah klimaterik hanya akan mengadakan reaksi respirasi apabila etilen diberikan dalam tingkat pra klimaterik dan tidak peka lagi terhadap etilen setelah kenaikan respirasi dimulai (Zuhairini, 1997). Proses pematangan bermula dari terjadinya hidrolisa substrat oleh campuran enzimenzim yang ada didalamnya. Selama 
proses hidrolisa terjadi pemecahan khlorofil, pati, pectin dan tannin. Dari hasil pemecahan senyaa-senyawa tersebut akan terbentuk bahan-bahan seperti etilen, pigmen, flavor, energi dan polipeptida. Selama prosess pematangan perubahan-perubahan yang terjadi adalah warna hijau pada buah berubah menjadi kuning atau merah; rasa asam berubah menjadi manis; tekstur menjadi lebih lunak; terbentuknya vitamin-vitamin; dan adanya aroma khas buah karena terbentuknya senyawa-senyawa valotil (Prabawati, 2008).

\section{Pengaruh jenis pembungkus}

kertas

a. Vitamin $\mathbf{C}$

Berdasarkan tabel 1 dapat dilihat bahwa Jenis kertas yang digunakan terdapat pengaruh $(\mathrm{p}<0,05)$ terhadap kadar vitamin $\mathrm{C}$, jenis kertas mempengaruhi proses pematangan buah, jenis kertas yang mempercepat pematangan buah adalah jenis kertas bertinta. Jenis kertas bertinta yang poriporinya tertutup tinta akan memepercepat pematangan buah, dengan demikian semakin banyak vitamin yang dapat disintesis dalam pisang selama pemeraman.

Tabel 1. Hasil analisis Vitamin C berdasarkan jenis kertas pembungkus

\begin{tabular}{lc}
\multicolumn{1}{c}{ Jenis kertas } & $\begin{array}{r}\text { Vitamin C } \\
(\mathrm{mg} / 100 \mathrm{~g})\end{array}$ \\
\hline Kontrol & $47,52^{\mathrm{a}}$ \\
Kertas polos & $72,16^{\mathrm{b}}$ \\
Kertas bertinta & $84,48^{\mathrm{b}}$ \\
\hline
\end{tabular}

Keterangan : pemeraman hari ke-5

Tetapi, pada tabel 3 dapat diketahui bahwa penggunaan kertas polos dan kertas bertinta tidak terdapat perbedaan yang nyata $(p>0,05)$, hal ini dapat disebabkan karena kertas polos maupun bertinta sama-sama dapat mempercepat pematangan.

Menurut penelitian Sadat. A, dkk (2015) dengan judul "Pengaruh Pemeraman menggunakan Batu Karbit $\left(\mathrm{CaC}_{2}\right)$ terhadap sifat Fisik dan Kimia Buah Pisang Ambon (Musa Paradisiaca var. sapientum (L.) Kunt))" menyatakan bahwa kalsium karbida sebagai senyawa perangsang etilen akan mempercepat terjadinya proses pematangan buah, dengan demikian semakin banyak vitamin yang dapat disintesis dalam pisang selama pemeraman. Massa karbit yang digunakan mempengaruhi terhadap kadar vitamin $\mathrm{C}$, semakin tinggi massa karbit yang digunakan maka semakin tinggi kadar vitamin $\mathrm{C}$ yang dihasilkan pada buah (Siagian, 2009).

Adapun penelitian Sri Utami,dkk (2012) dengan judul "Pengaruh cara dan lama pemeraman terhadap kandungan Vitamin C pada buah Pisang Raja (Musa paradisiaca L)" dengan hasil laju kenaikan kandungan vitamin $\mathrm{C}$ buah pisang Raja ketika menuju puncak kematangan (klimaterik) dan penurunan kandungan vitamin $\mathrm{C}$ pada masa pasca klimaterik. Penurunan vitamin $\mathrm{C}$ disebabkan sifat vitamin $\mathrm{C}$ yang mudah larut dalam air, mempunyai sifat asam serta mudah teroksidasi. Sehingga vitamin $\mathrm{C}$ akan mengalami penurunan apabila dilakukan penyimpanan dalam waktu lama (Utami, 2012). Menurut Pantastico (1993), kandungan asam askorbat (vitamin C) akan mengalami penurunan selama penyimpanan terutama pada suhu penyimpanan yang tinggi. Kandungan asam askorbat menurun setelah penyimpanan kira-kira setengah hingga dua per tiga dari waktu panen. Hal ini disebabkan asam askorbat mudah teroksidasi, misalnya oleh enzim asam askorbat oksidase yang terdapat dalam jaringan tanaman (Zuhairini, 1997). 
Pada penelitian yang dilakukan, ketika buah diperam menggunakan kertas bertinta sebagai pembungkus maka etilen yang dihasilkan pada buah akan terperangkap didalam kertas pembungkus yang pori-porinya tertutup oleh tinta. Hal ini berkaitan dengan etilen yang terdapat pada buah. Etilen adalah senyawa hidrokarbon tidak jenuh yang pada suhu ruang berbentuk gas. Etilen juga merupakan suatu gas yang dalam kehidupan tanaman dapat digolongkan sebagai hormon yang aktif dalam proses pematangan. Pada hasil pertanian klimaterik, produksi etilen sangat efektif selama fase permulaan klimaterik, etilen disamping dapat memulai proses klimaterik, juga dapat mempercepat terjadinya klimaterik. Aktivitas etilen dalam pematangan buah akan menurun dengan turunnya suhu ruang penyimpanan (Prabawati, 2008).

Selain etilen, proses pematangan buah juga membutuhkan respirasi. Respirasi adalah suatu proses metabolism biologis dengan menggunakan oksigen dalam perombakan senyawa kompleks (seperti karbohidrat, protein, dan lemak) untuk menghasilkan $\mathrm{CO}_{2}$ air dan sejumlah besar elektron-elektron. Pada umumnya buah hasil pertanian setelah dipanen masih melakukan proses respirasi serta metabolism lain sampai bahan tersebut rusak dan proses kehidupan berhenti (Anna, 2012).

\section{b. Gula reduksi}

Tabel 2. Hasil analisis gula reduksi

berdasarkan jenis kertas pembungkus

\begin{tabular}{lc} 
Jenis kertas & $\begin{array}{c}\text { Gula Reduksi } \\
(\% / \mathrm{bb})\end{array}$ \\
\hline Kontrol & $1,43^{\mathrm{a}}$ \\
Kertas polos & $4,42^{\mathrm{b}}$ \\
Kertas bertinta & $5,90^{\mathrm{b}}$ \\
\hline
\end{tabular}

Keterangan : pemeraman hari ke-5
Berdasarkan tabel 2 menunjukkan bahwa adanya perbedaan yang nyata $(p<0,05)$ terhadap penggunaan jenis kertas pembungkus dengan meningkatnya kadar gula reduksi yang terdapat pada buah pisang ambon selama pemeraman. Kadar gula reduksi tertinggi terdapat pada pemeraman dengan menggunakan kertas bertinta yaitu 5,90\%. Menurut Mahapatra dkk (2010) selama proses pematangan buah pisang terjadi penurunan kandungan pati dari 20-30\% pada buah pisang yang mentah menjadi $1-2 \%$ pada buah pisang yang matang, sedangkan kandungan gula meningkat dari $1-2 \%$ pada buah pisa mentah menjadi $15-20 \%$ pada buah pisang matang (Muctadi, 2011). Tetapi, pada tabel 3 dapat diketahui bahwa penggunaan kertas polos dan kertas bertinta tidak terdapat perbedaan yang nyata $(p>0,05)$, hal ini dapat disebabkan karena kertas polos maupun bertinta sama-sama dapat mempercepat pematangan.

Menurut penelitian Hotman (2009) dengan judul "Penggunaan Bahan Penjerap Etilen pada penyimpanan Pisang Barangan dengan kemasan Atmosfer Termodifikasi Aktif" dengan hasil penelitian semakin lama penyimpanan maka kadar gula akan semakin meningkat. Hal ini disebabkan karena selama proses pematangan terjadi perombakan pati menjadi gula (Sunarjono, 2000). Menurut Sumadi, dkk (2004), pada awal pertumbuhan buah, konsentrasi gula total sangat rendah. Tetapi pada saat proses pemasakan, gula total meningkat tajam dalam bentuk glukosa dan fruktosa. Naiknya kadar gula yang tiba-tiba dapat digunakan sebagai indeks kimia kematangan (Tjitrosoepomo, 2000).

Pada penelitian yang dilakukan, ketika buah diperam menggunakan kertas bertinta sebagai pembungkus 
maka etilen yang dihasilkan pada buah akan terperangkap didalam kertas pembungkus yang pori-porinya tertutup oleh tinta. Hal ini berkaitan dengan etilen yang terdapat pada buah. Etilen adalah senyawa hidrokarbon tidak jenuh yang pada suhu ruang berbentuk gas. Etilen juga merupakan suatu gas yang dalam kehidupan tanaman dapat digolongkan sebagai hormon yang aktif dalam proses pematangan. Pada hasil pertanian klimaterik, produksi etilen sangat efektif selama fase permulaan klimaterik, etilen disamping dapat memulai proses klimaterik, juga dapat mempercepat terjadinya klimaterik. Aktivitas etilen dalam pematangan buah akan menurun dengan turunnya suhu ruang penyimpanan (Prabawati, 2008).

Selain etilen, proses pematangan buah juga membutuhkan respirasi. Respirasi adalah suatu proses metabolism biologis dengan menggunakan oksigen dalam perombakan senyawa kompleks (seperti karbohidrat, protein, dan lemak) untuk menghasilkan $\mathrm{CO}_{2}$ air dan sejumlah besar elektron-elektron. Pada umumnya buah hasil pertanian setelah dipanen masih melakukan proses respirasi serta metabolism lain sampai bahan tersebut rusak dan proses kehidupan berhenti (Anna, 2012).

\section{c. Organoleptik}

a) Rasa

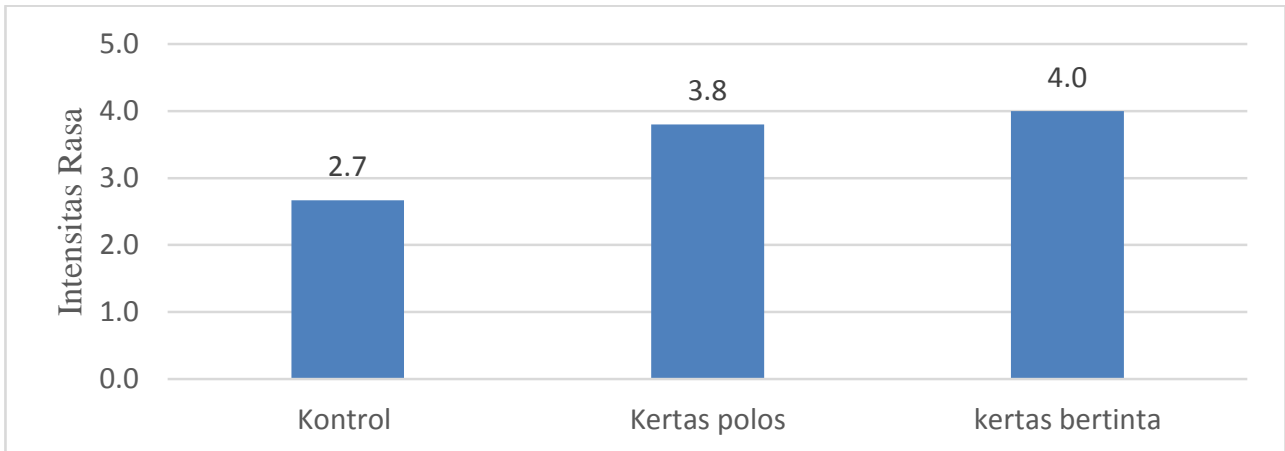

Keterangan : organoleptik dilakukan pada hari ke-5

Gambar 7. Diagram organoleptik atribut rasa pada pisang dengan perlakuan pemeraman terbuka (kontrol), kertas polos dan bertinta

Berdasarkan gambar 7 dapat dilihat bahwa rasa yang paling banyak disukai oleh panelis adalah pisang berasa manis yang diperam menggunakan kertas bertinta dengan rata-rata 4,0. Organoleptik dilakukan pada hari ke-5. Selama pemeraman rasa manis semakin meningkat dari rasa tidak manis menjadi manis pada pemeraman hari ke-5. Hal ini berkaitan dengan kadar gula yang meningkat selama pemeraman.
Perubahan komponen kimia terbesar dalam pematangan adalah perubahan karbohidrat yang menyebabkan perubahan rasa dan tekstur buah. Semakin matang buah, semakin tinggi kadar gula. Karena gula merupakan zat yang dominan dalam bahan padat yang terlarut pada buah makan tingkat kematangan sering ditentukan dengan soluble solid (Mikasari, 2004). 
b) Aroma

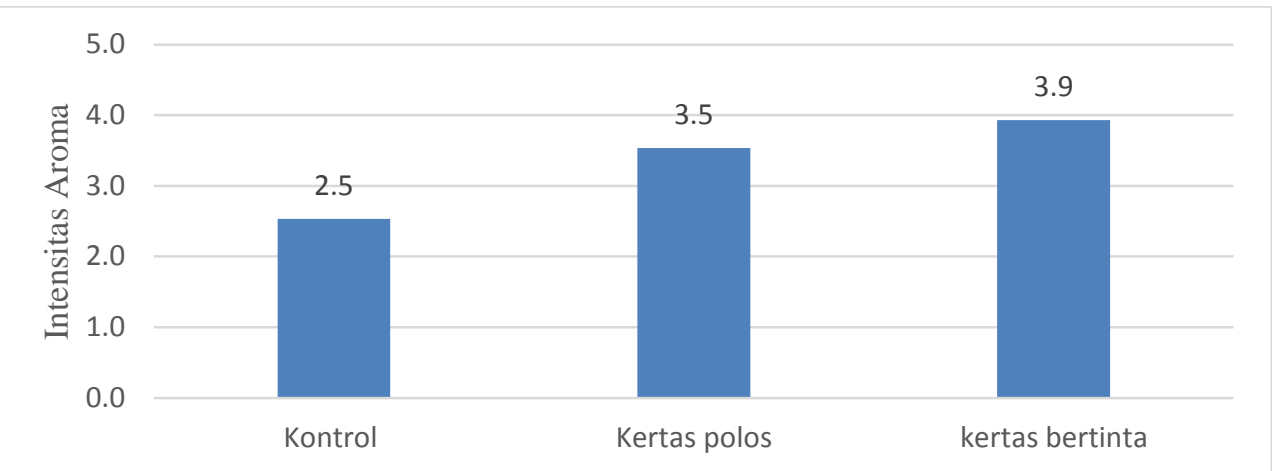

Keterangan : organoleptik dilakukan pada hari ke-5

Gambar 8. Diagram organoleptik atribut aroma pada pisang dengan perlakuan pemeraman terbuka (kontrol), kertas polos dan bertinta

Berdasarkan gambar 8 dapat menjadi wangi pada pemeraman hari kedilihat bahwa aroma yang paling banyak 5. Hal ini sesuai dengan teori yang disukai oleh panelis adalah pisang menyatakan bahwa, senyawa kimia dengan aroma wangi khas pisang yang utama dalam aroma buah adalah ester diperam menggunakan kertas bertinta dari alkohol alifatik dan asam-asam dengan rata-rata 3,9. Organoleptik lemak berantai pendek. Senyawa violatil dilakukan pada hari ke-5. Selama diproduksi dan dikeluarkan oleh buah pemeraman aroma wangi semakin hanya apabila buah mulai matang meningkat dari aroma tidak wangi (Prabawati, 2008).

c) Warna

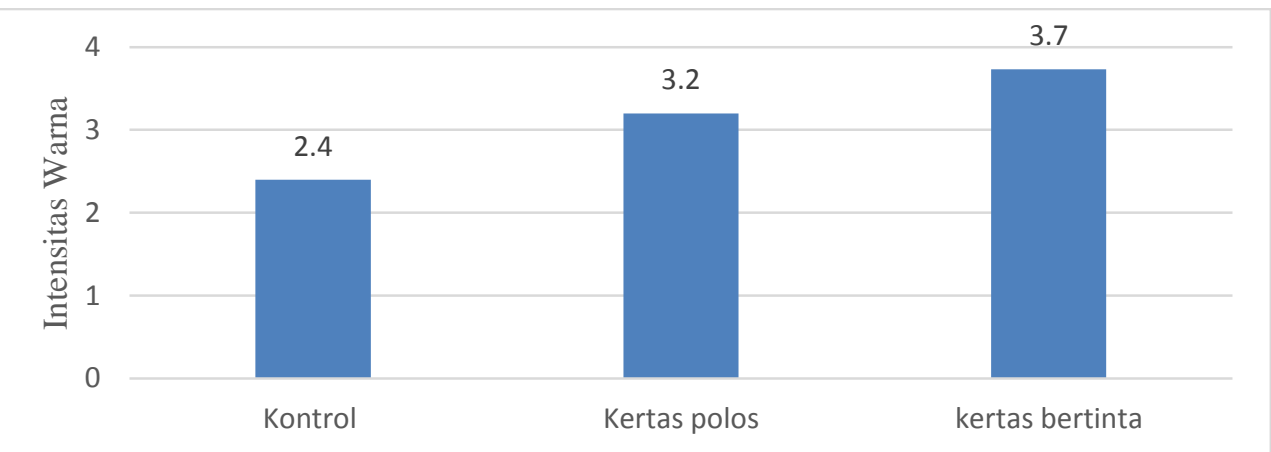

Keterangan : organoleptik dilakukan pada hari ke-5

Gambar 9. Diagram organoleptik atribut warna pada pisang dengan perlakuan pemeraman terbuka (kontrol), kertas polos dan bertinta

Berdasarkan gambar 9 dapat dilihat bahwa warna yang paling banyak disukai oleh panelis adalah pisang dengan warna kuning yang diperam menggunakan kertas bertinta dengan rata-rata 3,7. Organoleptik dilakukan pada hari ke-5. Selama pemeraman warna kuning semakin meningkat dari warna tidak kuning menjadi kuning pada pemeraman hari ke-5. Perubahan warna adalah perubahan yang paling terlihat ketika proses pematangan buah. Buah yang belum masak berwarna hijau karena masih banyak mengandung 
klorofil (Setyo, 2006). Pada umumnya sebagian besar buah, menghilangnya warna hijau merupakan pertanda kematangan. Selama pematangan kandungan klorofil pada buah menurun secara perlahan. Hilangnya warna hijau pada buah, karena terjadinya oksidasi atau penjenuhan terhadap ikatan rangkap molekul klorofil (Prabawati, 2008).

d) Tekstur

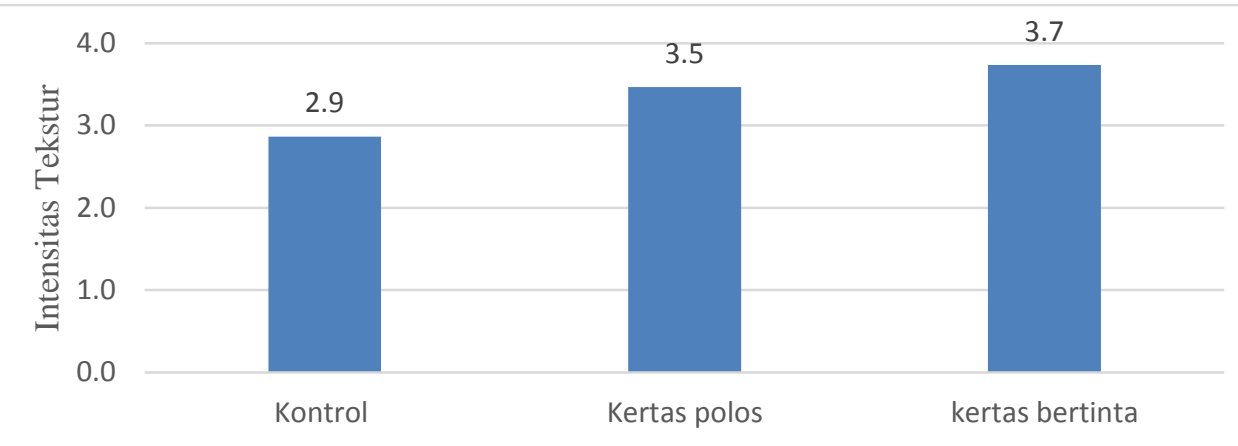

Keterangan : organoleptik dilakukan pada hari ke-5

Gambar 10. Diagram organoleptik atribut tekstur pada pisang dengan perlakuan pemeraman terbuka (kontrol), kertas polos dan bertinta

Berdasarkan gambar 10 dapat dilihat bahwa tekstur yang paling banyak disukai oleh panelis adalah pisang tekstur lunak yang diperam menggunakan kertas bertinta dengan rata-rata 3,7. Organoleptik dilakukan pada hari ke-5. Selama pemeraman tekstur lunak semakin meningkat dari tekstur tidak lunak menjadi lunak pada pemeraman hari ke-5. Hal ini berkaitan dengan tekanan turgor sel selalu berubah selama proses perkembangan dan pematangan. Perubahan ini umumnya disebabkan karena komposisi dinding sel berubah. Adanya perubahan ini mempengaruhi kekerasan buah, bila buah matang. Pengempukan buah disebabkan menurunnya jumlah priktopektin yang tidak larut air dan naiknya jumlah pectin yang larut air (Prabawati, 2008).

\section{KESIMPULAN DAN SARAN}

\section{Kesimpulan}

1. Berdasarkan lama pemeraman buah pisang ambon kuning, semakin lama waktu yang dibutuhkan dalam proses pemeraman maka kadar vitamin $\mathrm{C}$ dan gula reduksi semakin meningkat. Kadar vitamin C dan gula reduksi tertinggi terdapat pada pemeraman hari ke-5.

2. Jenis kertas pembungkus pada pemeraman buah pisang ambon kuning yang dapat mempercepat proses pematangan adalah jenis kertas bertinta. Kadar vitamin C dan gula reduksi tertinggi terdapat pada jenis kertas bertinta. Uji organoleptik yang paling disukai oleh panelis adalah pisang ambon kuning yang diperam menggunakan kertas bertinta. 


\section{Saran}

1. Bagi peneliti selanjutnya sebaiknya mencoba menggunakan jenis kertas dan jenis tinta yang berbeda.

2. Bagi peneliti selanjutnya sebaiknya mencoba memeram buah pisang dengan kertas pembungkus lebih dari 5 hari.

3. Bagi peneliti selanjutnya sebaiknya meneliti suhu didalam kertas pembungkus saat pemeraman.

4. Bagi masyarakat agar memilih media yang alami untuk pemeraman buah agar buah tidak cepat membusuk dan rontok.

\section{DAFTAR PUSTAKA}

Anna YE. 2012. Pengaruh Jenis Perangsang Pematangan Terhadap Mutu Buah Terung Belanda (Cyphomandra betacea).

Asif M. 2012. Physico-chemical properties and toxic effect of fruitripening agent calcium carbide. Ann Trop Med Public Health.

Gardjito MD. 2013. Pangan Nusantara Karakteristik dan Prospek untuk Percepatan Diversifikasi Pangan. Kencana Prenada Media Group. Jakarta.

Harris R. EK. 1989. Evaluasi Gizi pada Pengolahan Bahan Pangan.ITB Press. Bandung.

Mikasari W. 2004. Kajian Penyimpanan dan Pematangan Buah Pisang Raja (musa paradisiaca var sapientum L) dengan metode penetapan suhu. Sekolah Tinggi Institusi Pertanian Bogor; Bogor.

Muchtadi D. 2011. Karbohidrat Pangan dan Kesehatan.Alfabeta. Bandung Muchtadi, T RSAF. 2011. Ilmu Pengetahuan Bahan Pangan. Alfabeta. Bandung.

Pantastico ERB. 1993. Fisiologi Pasca Panen, Penanganan dan Pemanfaatan Buah-Buahan dan Sayuran Tropika dan Subtropika. UGM Press. Yogyakarta.

Prabawati, S. S dan S DA. 2008. Teknologi Pascapanen dan Teknik Pengolahan Buah Pisang. Balai Besar Penerbitan dan Pengembangan Pertanian.

Sakti. Buah Matang, Buah Masak dan Kualitasnya [Internet]. 2008 [cited 2017 Feb 17]. Available from: http://www.intitusi.com

Setyo EM dan LK. 2006. Pisang Peluang Bisnis yang menjanjikan. Argo Media Pustaka. Jakarta.

Siagian HF. 2009. Penggunaan Bahan Penjerat Etilen pada Penyimpanan Pisang Barangan dengan Kemasan Atmosfer termodifikasi aktif.

Suhartanto, M RS dan HH. 2012. Teknologi Sehat Budidaya Pisang dari Benih Sampai Pasca Panen. Pusat Kajian Hortikultura Tropika.

Sunarjono. 2000. Prospek Tanaman Buah. Penebar Swadaya. Jakarta.

Tjitrosoepomo G. 2000. Morfologi Tumbuhan. UGM Press. Yogyakarta.

Utami SWJ. 2012;2. Pengaruh Cara dan Lama Pemeraman terhadap Kandungan Vitamin C pada Buah Pisang Raja (Musa paradisiaca L). J Edukasi Mat dan Sains.

Zuhairini E. 1997. Budidaya Pisang Raja.Trubus Agrisarana. Surabaya. 